DOE/ID/13987

Horizontal Wells to Enhance Production in the Bottle Rock Field

Final Report - 09/30/2000 - 02/01/2001

J. H. Cohen

February 2001

Work Performed Under Contract No. DE-FG07-00ID13987

For

U.S. Department of Energy

Assistant Secretary for

Environmental Management

Washington, DC

By

Maurer Engineering

Houston, TX 


\section{DOE/ID/13987}

\section{HORIZONTAL WELLS TO ENHANCE PRODUCTION IN THE BOTTLE ROCK FIELD \\ FINAL REPORT \\ 09/30/2000 - 02/01/2001}

J. H. Cohen

February 2001

Work Performed Under Contract No. DE-FG-00ID13987

Prepared for the

U.S. Department of Energy

Assistant Secretary for

Environmental Management

Washington, DC

Prepared by

Maurer Engineering

Houston, TX 


\title{
HORIZONTAL WELLS TO ENHANCE PRODUCTION IN THE BOTTLE ROCK FIELD Phase I Final Report
}

Contract No. DE-FG07-00ID13987

Submitted to:

U.S. DOE, Idaho Operations Office

850 Energy Drive

Idaho Falls, Idaho 83401-1563

\author{
By: \\ Maurer Engineering \\ 2916 West T.C. Jester \\ Houston, TX 77018-7098 \\ Phone: 713-683-8227
}

TR01-4

February 2001 


\section{HORIZONTAL WELLS TO ENHANCE PRODUCTION IN THE BOTTLE ROCK FIELD \\ Phase I Final Report}

\section{Introduction}

This report is submitted by Maurer Engineering Inc. (MEI) to fulfill close-out requirements for the Enhanced Geothermal Systems (EGS) Project. A detailed report/proposal entitled, "Horizontal Wells to Enhance Production in the bottle Rock Field - Phase II Proposal," was previously submitted to the DOE as the deliverable under contract number DE-FG07-00ID13987. This final report summarizes the activities that provided the information contained in the proposal for Phase II.

\section{Review Bottle Rock Records}

The first step in preparation of the Phase II proposal was to gather and sort through the historical records from the Bottle Rock geothermal field. These records included geologic, production, and drilling data. This information was used to help prepare the proposal and will serve as a basis of comparison in Phase II when the EGS plan is implemented.

Significant volumes of data were documented while the Bottle Rock field was active. A major portion of the effort for this project was separating useful data from records that had no meaning or were not presented in a satisfactory format. After the useful data was separated, it was organized into a usable form for the proposal.

\section{Collect State Geologic And Production Records}

After sorting the Bottle Rock data, a search was made of state geologic and production records for the Geysers field. These data were combined with the Bottle Rock data to form a complete picture of the geology and producing formations for planning the EGS horizontal wells proposed in Phase II. The state records were also needed to develop environmental, safety, and permitting plans at the Bottle Rock facility.

\section{Define Horizontal Well EGS Concept}

A definition of the EGS plan to increase production in the Bottle Rock field was developed for the Phase II proposal. This plan used horizontaldrilling techniques adapted from the oil and gas industry to place horizontal or near-horizontal wellbores into high production zones in the Bottle Rock producing formation. Data from many sources, including the DOE Federal Energy Technology Center web page, technical papers, journal articles, and experiences from operators, were gathered to develop the EGS plan and to determine potential production increases expected from horizontal wells.

After the horizontal EGS model was defined, well planning software was used to develop a well path for the first EGS well. This plan included the kickoff point, the radius of curvature and horizontal distance to be drilled. A torque and drag program was used to ensure that the shape of the well did not inhibit or dramatically increase the 
difficulty of drilling the well. The design was incrementally changed based on the output from these programs until a satisfactory well path was established.

\section{Develop Geologic Model And Site Description}

A geologic model and site description were developed for the proposal based on historic Bottle Rock Data and the State geologic surveys. This model covered the physiographic features as well as the subsurface geology. Included was information on the underlying formations including drillability, stability, reservoir fluid properties, fracture characterization, and stereographic features. The productive zones as identified by historic and state records were defined along with the fracture profiles, depths, direction, and location of highly fractured zones. These data were used later in the design of the horizontal wells. Surface geology was used in developing environmental plans and in obtaining the necessary permits required by either the state of California or the U.S. Government.

Historic production data were extensively used to identify highly fractured zones that need to be exploited by horizontal well technology. State data on wells located on adjacent properties were used to confirm the estimated performance developed from the historic data.

\section{Develop EGS Financial Model}

The EGS definition, geologic model and feasible electric power rates were used to develop a financial model. This served to define production rates from the steam wells in the Bottle Rock field necessary to support the power plant and what potential revenues and profits can be produced. The model incorporated institutional, safety, environmental, and other cost issues. Results showed that, if reworked wells in the field produce steam at previous levels (equivalent to $20 \mathrm{MW}$ ), then the plant can be operated profitable. Application of the horizontal EGS well design will increase the plant's output and increase the return on investment into profitable levels to justify the capital expenditures necessary to re-open the facility.

\section{Develop Manageme nt Plan}

A management team was assembled comprised of personnel from Maurer Engineering and ThermaSource. In addition, select industry experts were contacted to form an Industry Advisory Committee. These elements were placed into an organizational chart to form a structure to efficiently carry out the EGS plan as described in the proposal. To guide the efforts of the management team, several documents were produced as part of the proposal. This included a work statement that outlines the major tasks that need to be accomplished. A schedule was made for the work statement so that the management team will be able to measure progress as the project is carried out. A detailed budget was compiled so that a means of cost control will be available. This budget process included making AFEs (Authorization for Expenditure) for each of the planned horizontal EGS wells, contacting and eliciting quotes from major suppliers and contractors, and determining labor needs for the project. All of this material was summarized into schedules of deliverables and project goals.

All of the available data were used to develop a proposal which was submitted to the DOE as the sole deliverable of the Phase I effort. 